\title{
Effects of ruminal and duodenal infusion of starch and protein on GH secretion in sheep*
}

\author{
A. Hagino ${ }^{1,3}$, K. Takahashi ${ }^{1}$, A. Matsuda ${ }^{1}$, M. Kawai ${ }^{1}$, Y. Ohtomo ${ }^{1}$, \\ S. Oda ${ }^{2}$, Y. Sasaki ${ }^{1}$, K. Katoh ${ }^{1}$ and Y. Obara ${ }^{1}$ \\ ${ }^{1}$ Department of Animal Physiology, Graduate School of Agricultural Science, Tohoku University \\ Sendai 981-8555, Japan \\ ${ }^{2}$ Department of Animal Nutrition, Faculty of Agriculture, Iwate University \\ Morioka 020-8550, Japan
}

\begin{abstract}
The effect of ruminal and duodenal infusion of maize starch and casein on plasma growth hormone $(\mathrm{GH})$ concentrations was studied in sheep. Plasma GH concentrations were decreased after feeding. Maize starch and casein infusion into the rumen prolonged the decrease after feeding whereas duodenal infusion of maize starch did not affect the decrease. Duodenal infusion of casein inhibited the decrease in GH after feeding. These data suggest that maize starch and casein are degraded by microbial fermentation and increased VFA production in the rumen may be involved in the prolonged decrease in GH secretion after feeding.
\end{abstract}

KEY WORDS: growth hormone, rumen, duodenum, feeding, starch, casein

\section{INTRODUCTION}

Feeding has been shown to cause a reduction in plasma GH concentrations in ruminants (Bassett, 1974). GH releasing hormone-induced release of GH was suppressed after feeding (Moseley et al., 1988), suggesting that feeding decreased the responsiveness of the anterior pituitary to secretory stimuli. Matsunaga et al. (1999) have reported that infusion of volatile fatty acids (VFA) into the rumen caused a decrease in GH concentrations in sheep and concluded that increased

\footnotetext{
* Supported by Grants-in-aid for Scientific Research from the Ministry of Education, Culture, Sports, Science and Technology in Japan

The authors thank Dr. M.T. Rose (The University of Wales) for his advice on this manuscript and NIDDK's National Hormone and Pituitary Program for providing ovine GH and GH antiserum

${ }^{3}$ Corresponding author: e-mail: hagino@bios.tohoku.ac.jp
} 
VFA concentrations may play a role forthe decrease in GH secretion after feeding. In their experiments $\mathrm{GH}$ concentrations were decreased gradually from $2 \mathrm{~h}$ after the start of VFA infusion whereas a rapid decrease in GH concentrations was observed after feeding and the decrease was continued for several h. However, it is still unclear how secretion of GH is suppressed during and for several $\mathrm{h}$ after feeding. The objectives of this experiment were to compare the effect of ruminal and duodenal infusion of starch and protein on GH secretion.

\section{MATERIAL AND METHODS}

\section{Animals}

Six sheep $(48.0 \pm 1.3 \mathrm{~kg})$ fitted with ruminal and duodenal cannulae were used. The animals were housed individually in metabolic cages and offered timothy hay $(1.0 \mathrm{~kg} / \mathrm{day})$ once daily at 12.00 and the residue was removed and weighed at 16.00. Water was available continuously.

\section{Experimental procedure}

Maize starch and casein were suspended in saline at $143 \mathrm{~g} / \mathrm{L}$ and $71.5 \mathrm{~g} / \mathrm{L}$, respectively. The suspensions were stirred using magnetic stirrer throughout the infusion. The suspensions were infused from 12.00 to 16.00 at $2.9 \mathrm{ml} / \mathrm{min}$ with a peristaltic pump into either the rumen or duodenum. The animals were grouped into three groups (control, maize starch and casein) for the two infusion sites (rumen and duodenum) and assigned to treatments randomly. The animals received each infusion for ten days and serial blood sampling was carried out on day 10 of each treatment from 10.00 to 22.00 at 15 min intervals through a polyethylene catheter inserted previously. Blood samples were centrifuged and the separated plasma samples were stored at $-20^{\circ} \mathrm{C}$ until they were analysed.

\section{Radioimmunoassay for $\mathrm{GH}$}

Plasma GH was measured by a double-antibody RIA using NIDDK oGHI-2 as a standard and anti-oGH-2 as a primary antibody (Kuhara et al., 1991). Sensitivity of the assay was $1.0 \mathrm{ng} / \mathrm{ml}$. The intra-assay coefficient of variation (C.V.) was $9.5 \%$.

\section{Statistical analysis}

Mean values as well as the standard errors of the means were calculated. The data were assigned to six 2-h periods. Significant differences between the periods were analysed by one-way analysis of variance (ANOVA) followed by Duncan's multiple range tests on the mean values calculated within the periods. 


\section{RESULTS}

Mean $2 \mathrm{~h}$ concentrations of plasma GH in animals infused with maize starch and casein into the rumen are presented in Table 1. GH concentrations before feeding were $22.0 \pm 1.9,22.9 \pm 2.6$ and $23.5 \pm 2.5 \mathrm{ng} / \mathrm{ml}$ for the control, maize starch and casein infusions, respectively, and were not different from each other. A significant decrease in plasma GH concentrations was observed after feeding in the control treatment, which continued for $4 \mathrm{~h}$. The starch and casein infusion caused a significant decrease in plasma GH concentrations after feeding, which lasted for $10 \mathrm{~h}$, substantially longer than that of the control infusion.

Table 1. Effect of ruminal infusion of maize starch and casein on plasma GH concentrations in sheep, $\mathrm{ng} / \mathrm{ml}$

\begin{tabular}{cccc}
\hline $\begin{array}{c}\text { Time of day } \\
\mathrm{H}\end{array}$ & Control & $\begin{array}{c}\text { Maize } \\
\text { starch }\end{array}$ & Casein \\
\hline $10-12$ & $22.0 \pm 1.9$ & $22.9 \pm 2.6$ & $23.5 \pm 2.5$ \\
$12-14$ & $10.7 \pm 1.4^{*}$ & $11.3 \pm 1.1^{*}$ & $11.9 \pm 2.0^{*}$ \\
$14-16$ & $13.1 \pm 3.2^{*}$ & $11.3 \pm 1.1^{*}$ & $10.3 \pm 2.3^{*}$ \\
$16-18$ & $18.2 \pm 1.5^{\mathrm{a}}$ & $16.1 \pm 1.5^{\mathrm{ab} *}$ & $11.5 \pm 1.1^{\mathrm{b} *}$ \\
$18-20$ & $20.4 \pm 2.8^{\mathrm{a}}$ & $14.5 \pm 0.7^{\mathrm{b} *}$ & $13.7 \pm 1.1^{\mathrm{b} *}$ \\
$20-22$ & $21.2 \pm 1.8$ & $18.3 \pm 1.8^{*}$ & $16.7 \pm 1.1^{*}$ \\
\hline
\end{tabular}

a,b different letters indicate significant difference $(\mathrm{P}<0.05){ }^{*}$ - $\mathrm{P}<0.05$ vs before feeding $(10-12 \mathrm{~h})$

Changes in mean $2 \mathrm{~h}$ concentrations of plasma GH after duodenal infusion of maize starch and casein are presented in Table 2. Prefeeding plasma GH concentrations for sheep infused with casein into the duodenum was significantly lower than that of the starch infusion. Casein infusion into the duodenum did not decrease plasma GH concentrations after feeding, while a slight decrease in plasma GH concentrations was observed after feeding for the control and starch infusions.

Table 2. Effect of duodenal infusion of maize starch and casein on plasma GH concentrations in sheep, $\mathrm{ng} / \mathrm{ml}$

\begin{tabular}{cccc}
\hline $\begin{array}{c}\text { Time of day } \\
\mathrm{h}\end{array}$ & Control & $\begin{array}{c}\text { Maize } \\
\text { starch }\end{array}$ & Casein \\
\hline $10-12$ & $17.9 \pm 3.9^{\mathrm{ab}}$ & $21.6 \pm 5.6^{\mathrm{a}}$ & $11.9 \pm 1.4^{\mathrm{b}}$ \\
$12-14$ & $11.5 \pm 1.0^{*}$ & $14.1 \pm 0.8$ & $9.5 \pm 0.5$ \\
$14-16$ & $12.6 \pm 2.0$ & $11.5 \pm 1.6$ & $9.2 \pm 1.7$ \\
$16-18$ & $11.9 \pm 2.9$ & $13.7 \pm 1.0$ & $10.3 \pm 1.9$ \\
$18-20$ & $15.4 \pm 1.3^{\mathrm{a}}$ & $15.8 \pm 1.9^{\mathrm{a}}$ & $8.5 \pm 0.7^{\mathrm{b}}$ \\
$20-22$ & $15.8 \pm 2.0$ & $19.3 \pm 4.0$ & $11.7 \pm 1.0$ \\
\hline
\end{tabular}

a,b different letters indicate significant difference $(\mathrm{P}<0.05)$; * $\mathrm{P}<0.05$ vs before feeding $(10-12 \mathrm{~h})$ 


\section{DISCUSSION}

Ruminal infusion of maize starch and casein caused a prolonged decrease in plasma GH concentrations compared with the control, whereas duodenal infusion of maize starch and casein did not. It has been reported that ruminal infusion of VFA suppressed plasma GH concentrations in sheep and the decrease in GH was caused 2-4 h after the onset of VFA infusion (Matsunaga et al., 1999), indicating ruminal VFA production after feeding might be involved in the prolonged decrease in GH secretion in sheep. Recent work (Sugino et al., 2002) in sheep demonstrates that plasma ghrelin levels increase before the onset of a meal, prompting an elevation in plasma $\mathrm{GH}$, and a decrease rapidly after a meal, which corresponds with the decrease in GH concentrations after feeding. It suggests that there is a tight relationship between plasma ghrelin levels and GH secretion in sheep. Ghrelin may play an important role in the reduction of plasma GH after feeding. However, to explain the involvement of ghrelin in GH decrease after feeding, further investigations are required.

\section{CONCLUSIONS}

Infusion of maize starch and casein into the rumen at feeding caused a prolonged decrease in plasma GH concentrations compared with control, whereas duodenal infusion of maize starch and casein did not. It suggests that maize starch and casein are degraded in the rumen and increased VFA production in the rumen may be involved in the prolonged GH reduction after feeding.

\section{REFERENCES}

Bassett J.M., 1974. Diurnal patterns of plasma insulin, growth hormone, corticosteroid and metabolite concentrations in fed and fasted sheep. Aust. J. Biol. Sci. 25, 1277-87

Kuhara T., Ikeda S., Ohneda A., Sasaki Y., 1991. Effet of intravenous infusion of seventeen amino acids on the secreton of GH, glucagons and insulin in sheep. Amer. J. Physiol. - Endocrinol. Met. 260, E21-E26

Matsunaga M., Arakawa N.T., Goka T., Nam K.T., Ohneda A., Sasaki Y., Katoh K., 1999. Effects of ruminal infusion of volatile fatty acids on plasma concentration of growth hormone and insulin in sheep. Domest. Anim. Endocrinol. 17, 17-27

Moseley W.M., Alaniz G.R., Claflin W.H., Krabill L.F., 1988. Food intake alters the serum growth hormone response to bovine growth hormone-releasing factor in meal-fed Holstein steers. J. Endocrinol. 117, 253-9

Sugino T., Hasegawa Y., Kikkawa Y., Yamaura J., Yamagishi M., Kurose Y., Kojima M., Kangawa K., Terashima Y., 2002. A transient ghrelin surge occurs just before feeding in a scheduled mealfed sheep. Biochem. Biophys. Res. Commun. 295, 255-260 